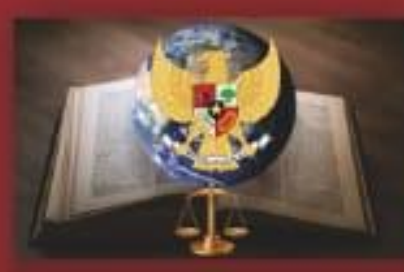

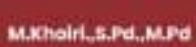

PEMBELAJARAN PPKn

ㅅ․

Buku Pembelajaran PPKn untuk Perguruan Tinggi merupakan buku pegangan (handout) yang sangat relevan bagi dosen pengampu Mata Kuliah Wajib Umum dan mahasiswa di Perguruan Tinggi.

Buku ini disusun berdasarkan dimensi-dimensi keilmuan yang dimiliki oleh penulis, buku ini juga didukung dengan pengalaman konkrit penulis sebagai pengampu mata kuliah PPKn dibeberapa Universitas, serta beberapa temuan penulis saat mengampu mata kuliah di program studi lain, selain program studi PPKn. Dimana mahasiswa-mahasiswa dari program studi lain diluar prodi PPKn secara umum sedikit sulit merangkum kesimpulan dari esensi perkuliahan antara materi Pendidikan Pancasila dan materi Pendidikan Kewarganegaraan di Perguruan Tinggi, sehingga penyusunan materi dalam buku ini disesuaikan dengan pemahaman awal secara mendasar hingga ketahap yang lebih spesifik dan meluas, guna mengembangkan wawasan mahasiswa secara periodik, hal tersebut sesuai dengan amanah Undang-Undang Nomor 12 Tahun 2012 Tentang Pendidikan Tinggi serta didukung dengan adanya Instruksi Presiden/Inpres Nomor 12 Tahun 2016 tentang "Gerakan Revolusi Mental" yang menekankan bahwa Mata Kuliah Wajib Umum PPKn merupakan komponen utama dalam membentuk karakter dan budaya bangsa Indonesia.

Materi dalam buku ini membahas tentang Pemahaman Awal Pendidikan Pancasila dan Kewarganegaraan, Sejarah, awal mula lahirnya Pancasila dan Pendidikan Kewarganegaraan (Civic Education), Dinamika perkembangan PPKn dalam ranah pendidikan di Indonesia, Konsep Pancasila dalam Arus Sejarah Bangsa Indonesia, Urgensi Pendidikan Pancasila dan Kewarganegaraan (menghadapi era revolusi industri), Peranan Pendidikan Pancasila dan Kewarganegaraan dalam Membangun Paradigma Demokrasi di Indonesia, Urgensi Hak dan Kewajiban Warga Negara, Konsep dan Urgensi Identitas Nasional, Konsep Ketahanan Nasional, Wawasan Kebangsaan dan Wawasan Nusantara, Peran PPKn dalam Membangun Karakter Bangsa, Memahami Konsep Negara, Pusparagam Pendidikan Kewarganegaraan di Berbagai Negara dan Perbandingan Ideologi Pancasila dengan Ideologiideologi yang ada di dunia.

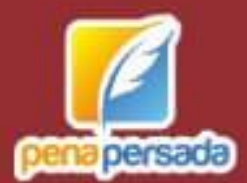

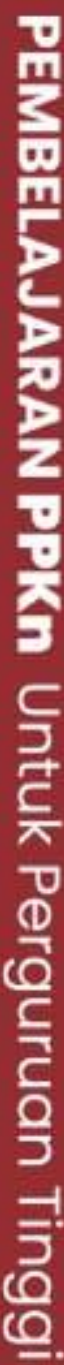

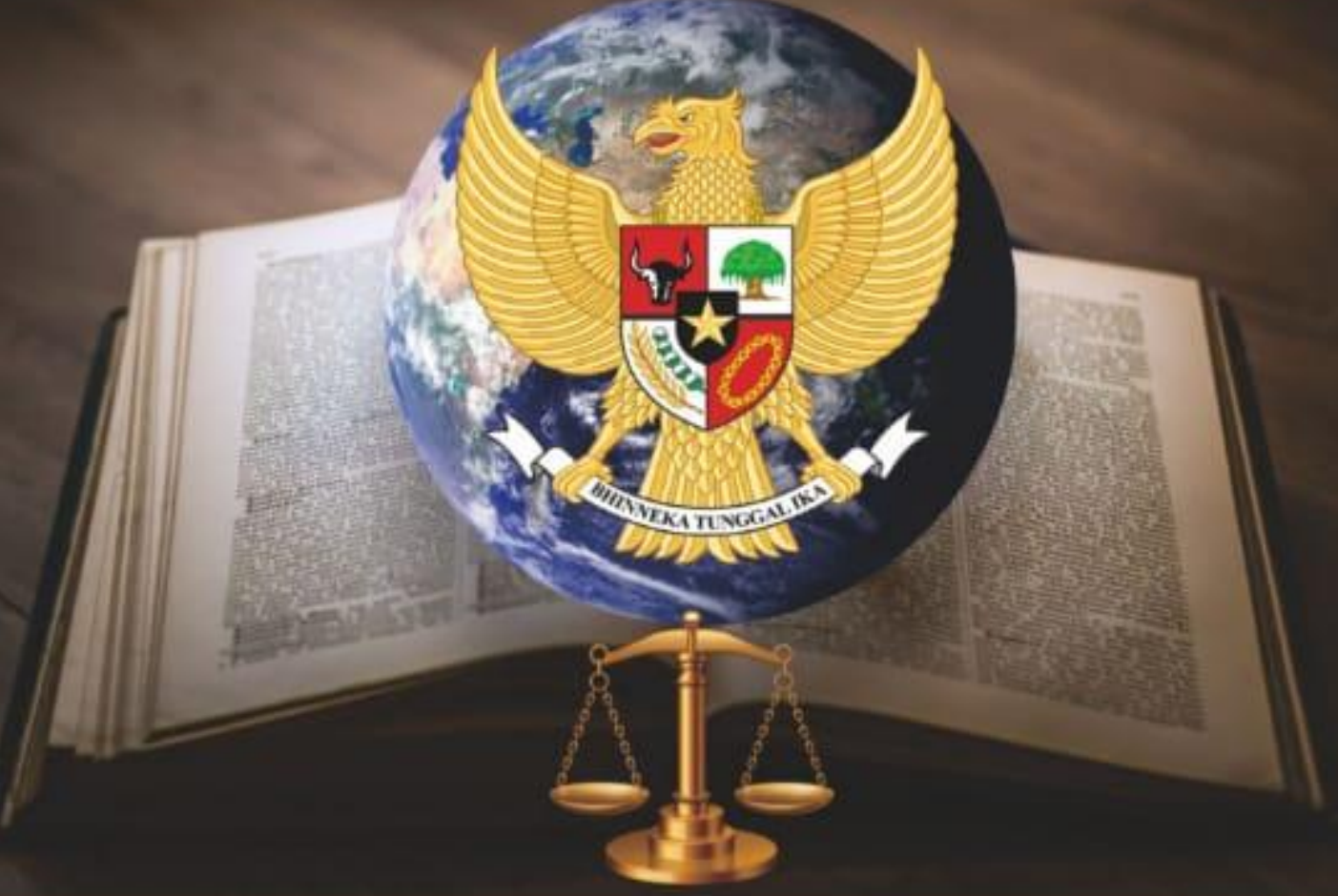

M.Khoiri.,S.Pd.,M.Pd

PEMBELAJARAN

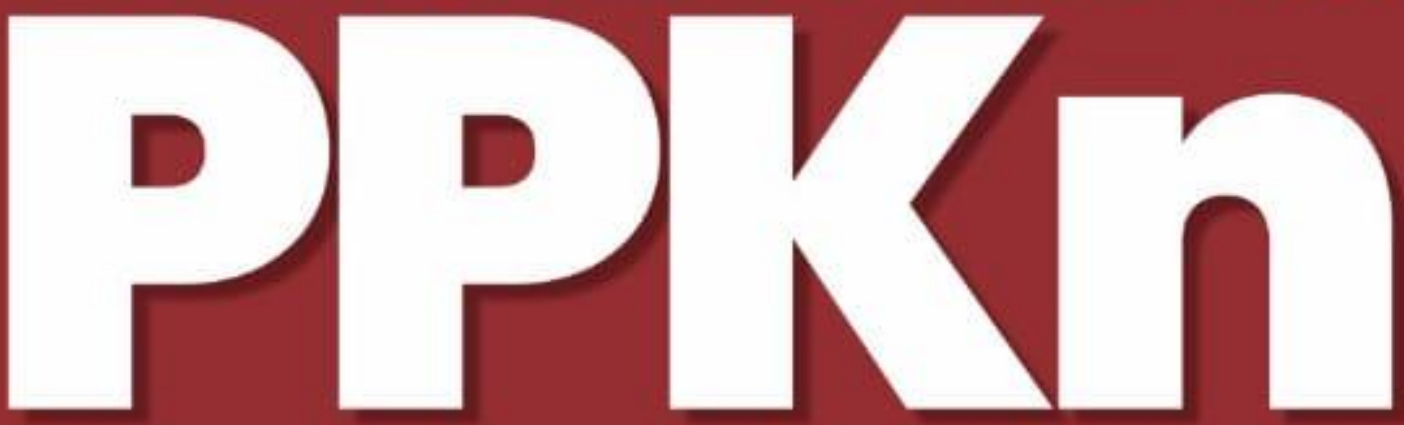

Untuk Perguruan Tinggi 


\section{PEMBELAJARAN PPKN UNTUK PERGURUAN TINGGI}

M. KHOIRI, S.Pd., M.Pd.

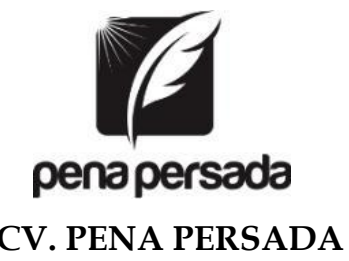




\title{
PEMBELAJARAN PPKN \\ UNTUK PERGURUAN TINGGI
}

\author{
Penulis : \\ M. Khoiri, S.Pd., M.Pd. \\ ISBN : 978-623-6837-78-8 \\ Design Cover : \\ Retnani Nur Briliant \\ Layout : \\ Hasnah Aulia \\ Penerbit CV. Pena Persada \\ Redaksi : \\ Tengah \\ Email : penerbit.penapersada@gmail.com \\ Website : penapersada.com \\ Phone : (0281) 7771388 \\ Anggota IKAPI \\ All right reserved \\ Cetakan pertama : 2020
}

Jl. Gerilya No. 292 Purwokerto Selatan, Kab. Banyumas Jawa

Hak cipta dilindungi oleh undang-undang.

Dilarang memperbanyak karya tulis ini dalam bentuk dan cara apapun tanpa izin penerbit 


\section{KATA PENGANTAR}

Selain disusun dengan mendasarkan pada dimensi-dimensi keilmuan yang dimiliki oleh penulis, buku ini juga didukung dengan pengalaman konkrit penulis sebagai pengampu mata kuliah PPKn dibeberapa Universitas, serta beberapa temuan penulis saat mengampu mata kuliah di program studi lain selain program studi PPKn, dimana mahasiswa program studi lain secara umum sedikit mengalami kesulitan dalam merangkum dan memahami esensi perkuliahan antara materi Pendidikan Pancasila dan materi Pendidikan Kewarganegaraan di Perguruan Tinggi, sehingga penyusunan materi dalam buku ini disesuaikan dengan pemahaman awal secara mendasar hingga ketahap yang lebih spesifik dan meluas, guna mengembangkan wawasan mahasiswa secara periodik.

Buku ini disusun dalam 13 bab, yang masing-masing diperincikan menjadi beberapa sub-sub bab yang lebih khusus. Diawal setiap bab disajikan tujuan instruksional baik secara umum maupun secara khusus. Para mahasiswa diharapkan mampu membaca dan menganalisis buku ini secara urut agar lebih mudah memahami esensi materi yang disampaikan pada setiap bab nya. Sehingga diperoleh kompetensi yang sesuai dengan tujuan instruksionalnya. Dan tentunya yang paling utama ialah puji dan syukur atas limpahan rahmat Allah SWT, dengan izin dan ridhoNya buku ini dapat diselesaikan dengan sebaik - baiknya. Buku ini merupakan buku yang disusun untuk mendukung mata kuliah Pendidikan Pancasila dan Kewarganegaraan khususnya "Mata Kuliah Wajib Umum untuk Perguruan Tinggi". Besar harapan penulis, dengan diterbitkannya buku ini diharapkan akan membentuk konstruksi pengetahuan dan membentuk sebuah paradigma mengenai pengetahuan tentang Pendidikan Pancasila dan Kewarganegaraan secara holistik. Buku ini juga diharapkan dapat memberikan sumbangan pengetahuan bagi mahasiswa khususnya dan bagi masyarakat serta akademisi pada umumnya, serta dapat membuka cakrawala berfikir bersama mengenai konsepsi pengetahuan. 
Akhir kata, penulis menyampaikan terimakasih kepada pihak yang telah berpartisipasi dan berkontribusi dalam proses penyusunan naskah buku ini. Harapan kita bersama semoga buku ini dapat memberikan manfaat bagi dunia pendidikan pada umumnya dan khususnya bagi mata kuliah PPKn. Dengan segenap kerendahan hati penulis memohon maaf yang sebesar besarnya apabila terdapat kesalahan dalam buku ini, kritik dan saran dari semua pihak tentunya penulis harapkan demi perbaikan kualitas buku ini.

Batam, 06 Desember 2020

M.Khoiri, S.Pd., M.Pd 


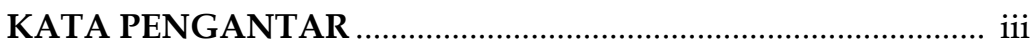

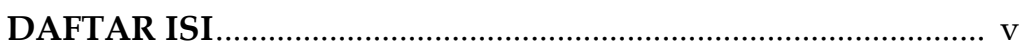

BAB I PENDAHULUAN

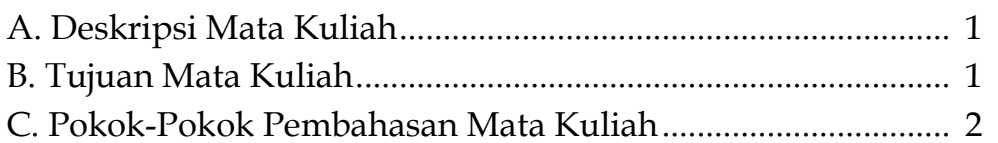

BAB II PEMAHAMAN AWAL TENTANG PPKn

A. Asal Mula Pancasila............................................................... 4

B. Asal Mula Pendidikan Kewarganegaraan

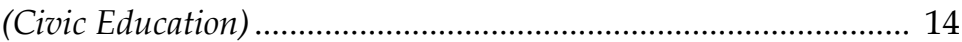

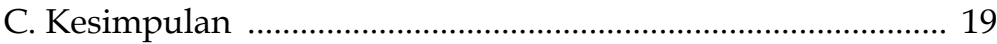

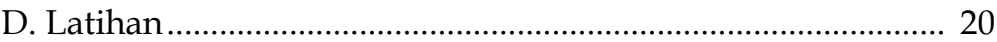

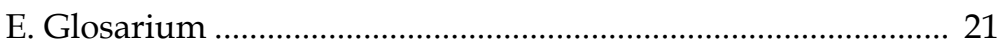

\section{BAB III DINAMIKA PERKEMBANGAN PKn} (CIVIC EDUCATION) DI INDONESIA

A. Sejarah PKn di Indonesia .......................................................... 22

B. Mata Kuliah Pendidikan Kewarganegaraan

(Civic Education) di Perguruan Tinggi ..................................... 25

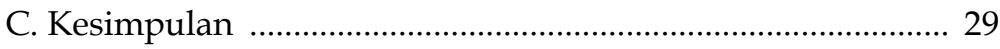

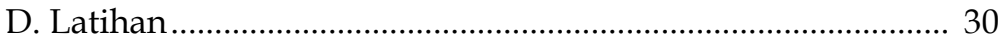

E. Glosarium ……….............................................................. 31

BAB IVKONSEP PANCASILA DALAM ARUS SEJARAH BANGSA

A. Periode Pengusulan Pancasila ................................................ 32

B. Periode Perumusan Pancasila ................................................... 35

C. Periode Pengesahan Pancasila .............................................. 38

D. Pancasila Sebagai Dasar Ideologi Negara ................................. 43

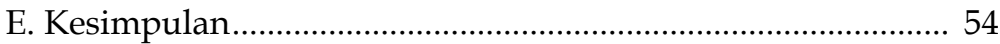

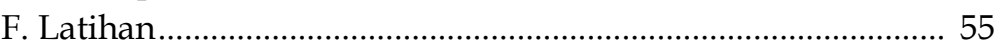

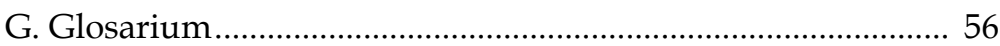

BAB V URGENSI PPKn

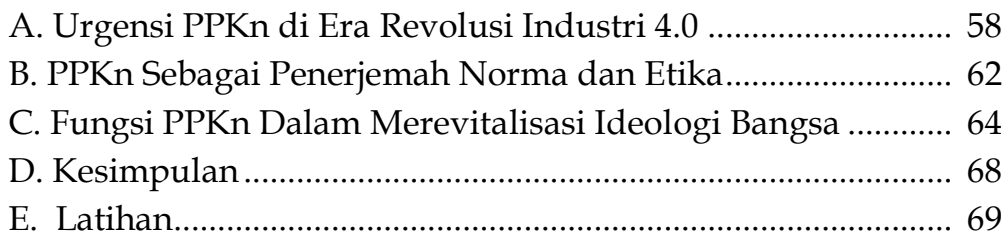


F. Glosarium 70

BAB VI PERAN PPKn DALAM MEMBANGUN PARADIGMA DEMOKRASI DI INDONESIA
A. Memahami Pengertian Demokrasi 71
B. Sikap Positif Terhadap Pelaksanaan Demokrasi..... 85
C. Kesimpulan 87
D. Latihan 89
E. Glosarium 89

BAB VII MENELUSURI KONSEP DAN URGENSI HAK DAN KEWAJIBAN WARGA NEGARA
A. Harmoni Kewajiban dan Hak Warganegara 90
B. Menggali Sumber Historis, Sosiologis dan Politik
Tentang Harmoni Kewajiban dan Hak Warganegara 92
C. Dinamika dan Tantangan
Harmoni Kewajiban dan Hak Warganegara......................... 95

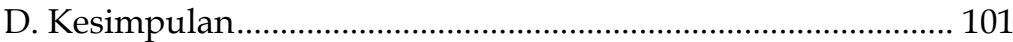
E. Latihan ........................................................................... 102
F. Glosarium ......................................................................... 102

BAB VIII MENELUSURI KONSEP DAN URGENSI IDENTITAS NASIONAL
A. Konsep dan Urgensi Identitas Nasional 103
B. Unsur-Unsur Identitas Nasional 105
C. Faktor Pendukung Lahirnya Identitas Nasional 107
D. Fungsi dan Urgensi Identitas Nasional 108
E. Dinamika dan Tantangan Identitas Nasional 110
F. Solusi Terhadap Dinamika dan Tantangan Identitas Nasional 112
G. Alasan Diperlukannya Identitas Nasional ........................... 113
H. Kesimpulan .......................................................................... 115

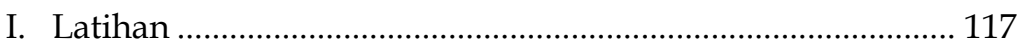
J. Glosarium ........................................................................ 117

BAB IX MEMAHAMI KONSEP TANNAS, WAWASAN KEBANGSAAN DAN WAWASAN NUSANTARA
A. Ketahanan Nasional 118
B. Wajah Ketahanan Nasional Indonesia................................... 123
C. Wawasan Kebangsaan dan Wawasan Nusantara .................. 128
D. Kesimpulan........................................................................... 133
E. Latihan .................................................................................... 134 
F. Glosarium

BAB $X$ PERAN PPKn DALAM MEMBANGUN KARAKTER BANGSA

A. Membangun Karakter Warganegara.......................................... 136

B. Pentingya Memahami Norma................................................ 137

C. Pentingnya Memahami Etika ................................................... 141

D. Pancasila Sebagai Sistem Norma dan Etika............................. 143

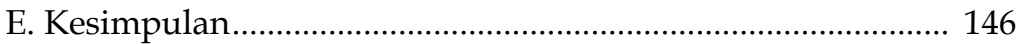

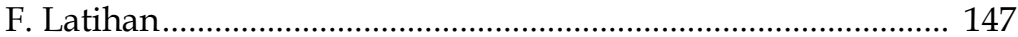

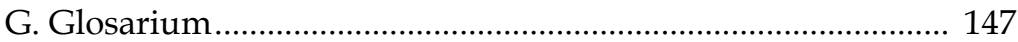

BAB XI MEMAHAMI KONSEP NEGARA

A. Memahami Konsep Negara .................................................... 149

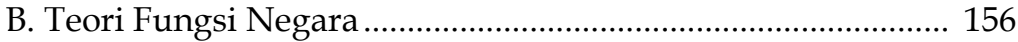

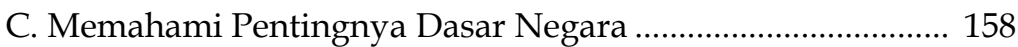

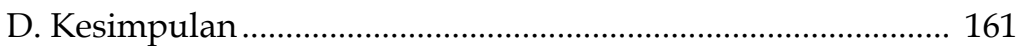

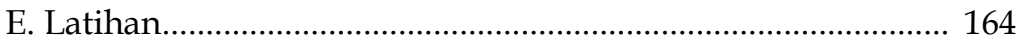

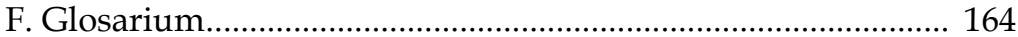

BAB XII PUSPARAGAM PENDIDIKAN KEWARGANEGARAAN DI BERBAGAI NEGARA

A. Kebijakan PKn (Civic Education) di Australia .......................... 165

B. Tatanan PKn (Civic Education) di Jepang ................................ 171

C. Kebijakan Pembelajaran PKn (Civic Education)

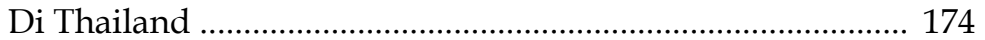

D. Pendidikan Kewarganegaraan (Civic Education)

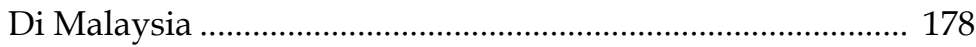

E. Pendidikan Kewarganegaraan (Civic Education)

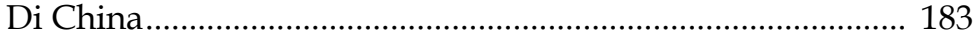

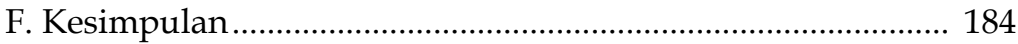

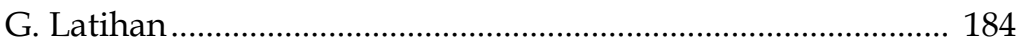

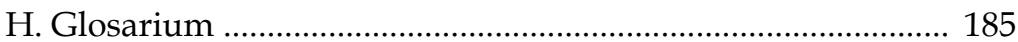

BAB XIII PERBANDINGAN IDEOLOGI PANCASILA DAN IDEOLOGI-IDEOLOGI DI DUNIA
A. Ideologi Pancasila 186

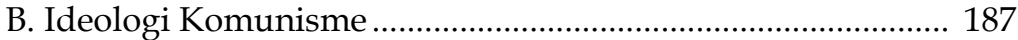

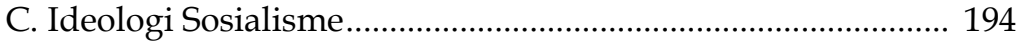

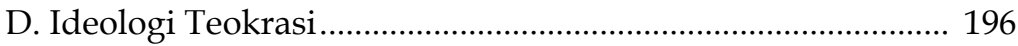

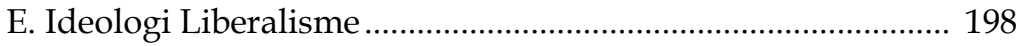




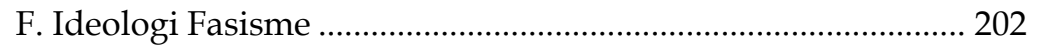

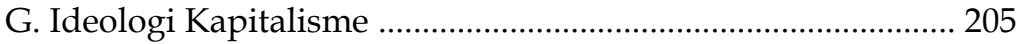

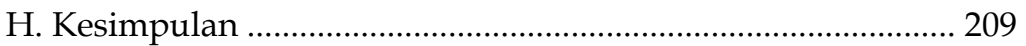

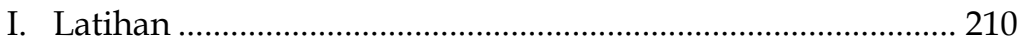

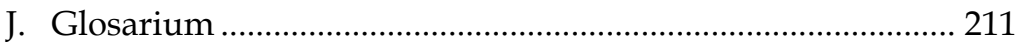

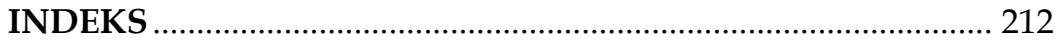

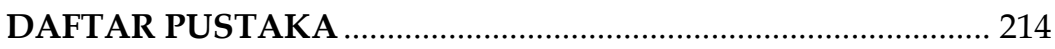

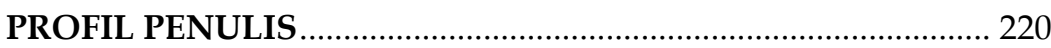




\section{BAB I \\ PENDAHULUAN}

\section{A. Deskripsi Mata Kuliah}

Pembelajaran PPKn untuk Perguruan Tinggi merupakan Mata Kuliah Wajib Umum bagi setiap jenjang jurusan/program studi yang terdapat di Perguruan Tinggi seluruh Indonesia, hal tersebut sesuai dengan Undang-Undang Nomor 12 Tahun 2012 Tentang Pendidikan Tinggi serta didukung dengan adanya Instruksi Presiden/Inpres Nomor 12 Tahun 2016 tentang "Gerakan Revolusi Mental" yang menekankan bahwa Pendidikan Mata Kuliah Wajib Umum PPKn merupakan komponen utama dalam membentuk karater dan budaya bangsa. Mata kuliah ini membahas tentang Pemahaman Awal Pendidikan Pancasila dan Kewarganegaraan, Sejarah, Awal Mula Lahirnya Pancasila dan Pendidikan Kewarganegaraan (Civic Education), Dinamika Perkembangan PPKn dalam Ranah Pendidikan di Indonesia, Konsep Pancasila dalam Arus Sejarah Bangsa, Urgensi Pendidikan Pancasila dan Kewarganegaraan dalam Menghadapi Era Revolusi Industri, Peranan Pendidikan Pancasila dan Kewarganegaraan dalam Membangun suatu Paradigma Demokrasi di Negara Indonesia, Urgensi Hak dan Kewajiban Warga Negara, Konsep dan Urgensi Identitas Nasional, Konsep Ketahanan Nasional, Wawasan Kebangsaan dan Wawasan Nusantara, Peran PPKn dalam Membangun Karakter Bangsa, Memahami Konsep Negara, Pusparagam Pendidikan Kewarganegaraan di Berbagai Negara dan Perbandingan Ideologi Pancasila dengan Ideologi-Ideologi lain yang ada di Dunia.

\section{B. Tujuan Mata Kuliah}

Tujuan Mata Kuliah Pembelajaran Pendidikan Pancasila dan Kewarganegaraan (PPKn) untuk Perguruan Tinggi adalah agar mahasiswa mampu memahami Sejarah, awal mula 
lahirnya Pancasila dan Pendidikan Kewarganegaraan (Civic Education), Dinamika Perkembangan PPKn dalam Ranah Pendidikan di Indonesia, Konsep Pancasila dalam Arus Sejarah Bangsa, Urgensi Pendidikan Pancasila dan Kewarganegaraan dalam menghadapi Era Revolusi Industri, Peranan Pendidikan Pancasila dan Kewarganegaraan dalam Membangun suatu Paradigma Demokrasi di Negara Indonesia, Urgensi Hak dan Kewajiban Warga Negara, Konsep dan Urgensi Identitas Nasional, Konsep Ketahanan Nasional, Wawasan Kebangsaan dan Wawasan Nusantara, Peran PPKn dalam membangun Karakter Bangsa. Serta memiliki Wawasan PPKn secara global.

\section{Pokok-Pokok Pembahasan Mata Kuliah}

Pokok-pokok pembahasan yang terdapat didalam Mata Kuliah ini diantaranya ialah sebagai berikut :

1. Pemahaman Awal Tentang Pendidikan Pancasila dan Kewarganegaraan (Sejarah, asal mula Pancasila serta Pendidikan Kewarganegaraan).

2. Dinamika Perkembangan Pkn di Indonesia (awal mula lahirnya Pendidikan Kewarganegaraan (Civic Education), Pentingnya PKn di Perguruan Tinggi).

3. Konsep Pancasila dalam Arus Sejarah Bangsa (periode pengusulan, perumusan, pengesahan dan penetapan Pancasila sebagai Ideologi bangsa/dasar negara).

4. Urgensi Pendidikan Pancasila dan Kewarganegaraan dalam menghadapi Era Revolusi Industri.

5. Peran PPKn dalam Membangun Paradigma Demokrasi di Indonesia.

6. Menelusuri Urgensi Hak dan Kewajiban Warganegara.

7. Menelusuri Konsep dan Urgensi Identitas Nasional.

8. Memahami Konsep Ketahanan Nasional, Wawasan Kebangsaan dan Wawasan Nusantara.

9. Memahami Peran PPKn Dalam Membangun Karakter Bangsa.

10. Memahami Konsep Negara.

11. Memahami Ragam PKn diberbagai Negara.

12. Memahami Perbandingan Ideologi Pancasila dan IdeologiIdeologi yang ada di Dunia. 


\section{BAB II \\ PEMAHAMAN AWAL \\ TENTANG PPKn}

Tujuan Instruksional :

\section{Tujuan Instruksional Umum}

Setelah membaca materi mahasiswa dapat mengetahui dan memahami sejarah dan asal mula Pancasila serta sejarah dan asal mula Pendidikan Kewarganegaraan.

2. Tujuan Instruksional Khusus

Setelah mengikuti perkuliahan mahasiswa diharapkan mampu

a. Menjelaskan sejarah dan asal mula Pancasila

b. Menjelaskan sejarah dan asal mula Pendidikan Kewarganegaraan

c. Memaknai dan mengidentifikasi sejarah, asal mula Pancasila dan Pendidikan Kewarganegaraan.

Pancasila sebagai ideologi dan dasar falsafah kehidupan bangsa Indonesia telah mengalami dinamika yang begitu panjang. Pancasila sebagai kristalisasi kebudayaan dan nilai luhur kehidupan bangsa Indonesia telah melalui beberapa fase, sejak zaman kerajaan-kerajaan Nusantara hingga terbentuknya sebuah Negara Indonesia. Fase sejarah yang telah dilalui Pancasila merupakan kekuatan hostoris yang dimiliki bangsa Indonesia sehingga menjadikan posisi Pancasila sebagai hal yang fundamental dan diyakini kebenaran akan nilai-nilai didalamnya. Sejarah mencatat bahwa keagungan akan falsafah Pancasila telah berkembang dalam kehidupan bangsa Indonesia sejak zaman Kerajaan seperti ketika pada zaman Kerajaan Kutai Kerta Negara, zaman Kerajaan Sriwijaya hingga pada zaman Kerajaan Majapahit. Hal tersebut semakin menunjukan bukti bahwa mengapa Pancasila merupakan kristalisasi dari kebudayaan bangsa Indonesia yang begitu diyakini akan Nilai-nilai kebaikan didalamnya. 


\section{A. Sejarah dan Asal Mula Pancasila}

\section{Pancasila pada Zaman Kerajaan di Indonesia}

Sebelum menjadi sebuah Negara yang berdaulat, Indonesia telah melalui fase panjang dalam perjalanan historisnya dimulai ketika menjadi sebuah bangsa yang besar ketika di zaman Pra Sejarah atau di zaman pra kolonialisme bangsa Indonesia dikenal dengan Nusantara, Nusantara memberikan bukti akan jejak sejarah kerajaankerajaan yang pernah hidup dan membawa nilai Pancasila didalamnya, diantara kerajaan-kerajaan yang membawa bukti kebenaran akan nilai Pancasila yang hidup dan berkembang dimasanya adalah pada zaman Kerajaan Kutai Kertanegara. Sebagai bukti keberadaan nilai-nilai luhur Pancasila pada zaman kerajaan Kutai Kertanegara disajikan dalam pembahasan sebagai berikut.

a. Pancasila pada Zaman Kerajaan Kutai Kertanegara

Pada tahun 400 masehi atau pada zaman pra sejarah dan pra kolonialisme bumi Nusantara (saat ini Indonesia) memiliki salah satu kerajaan yang berdiri dengan megah dan dikenal oleh seluruh penjuru dunia dengan nama Kerajaan Kutai Kertanegara. Kerajaan ini dipimpin oleh seorang raja yang bernama "Raja Mulawarman", bukti hidupnya nilai-nilai luhur Pancasila pada zaman kerajaan Kutai Kertanegara adalah dengan diberlakukannya sistem nilai yang mengajarkan kebaikan terhadap sesama antara kaum bangsawan dan golongan masyarakat biasa atau rakyat kerajaan biasa. Raja Mulawarman merupakan seorang raja yang dikenal dengan kearifannya atau seseorang yang bijaksana, dimana ia mampu mengayomi dan mensejahterakan masyarakatnya pada zaman itu.

Masyarakat yang hidup dengan berlandaskan nilai-nilai kebaikan yang ditetapkan sang raja telah memberikan dampak terhadap kehidupan rakyat kerajaan sehingga menjadi tenteram dan harmonis. Hal tersebut dibuktikan dengan kebebasan rakyat dalam 
menjalankan kehidup-annya seperti beribadah, bekerja dan memenuhi kewajiban upeti (membayar pajak) yang dimanfaatkan untuk kepentingan kesejahteraan rakyat Kutai Kertanegara.

Melalui perintah Raja untuk tetap menjaga nilainilai kebaikan pada rakyat kerajaan, ditaati oleh seluruh rakyat Kerajaan Kutai Kertanegara, karena Raja Mulawarman dikenal sebagai seorang yang dermawan dan peduli terhadap nasib rakyatnya, kebijakan Raja dipandang sebagai hal yang sangat penting untuk dituruti oleh semua pihak. Kerajaan Kutai adalah kerajaan tertua di Indonesia dan se-Asia Tenggara yang bercorak Hindu. Kerajaan Kutai terletak di muara Kamam Kalimantan Timur di Sungai Mahakam. Raja pertama dan sekaligus pendiri kerajaannya adalah raja Kudungga. Raja Kudungga memiliki seorang anak yang bernama Aswawarman. Aswawarman dijadikan raja oleh Raja Kudungga. Setelah berpindah tangan, Raja Aswawarman memiliki tiga orang anak yang salah satunya bernama Mulawarman.

Mulawarman pada saat itu diamanahkan untuk menggantikan Aswawarman. Pada saat pemerintahan Mulawarman, Kerajaan Kutai mengalami masa keemasannya. Wilayah kekuasaannya meliputi hampir seluruh kawasan Kalimantan Timur. Pada saat itu raja mulawarman memberi 20.000 ekor lembu kepada para Brahmana. Atas kebaikannya itu, para Brahmana membuatkan tujuh buah Yupa sebagai tanda terima kasih. Hal tersebut menunjukan nilai sosial politik dan Ketuhanan telah ada pada kerajaan Kutai. Dimana bentuk kerajaan dengan agama yang dijadikan sebagai pengikat kewibawaan raja. 


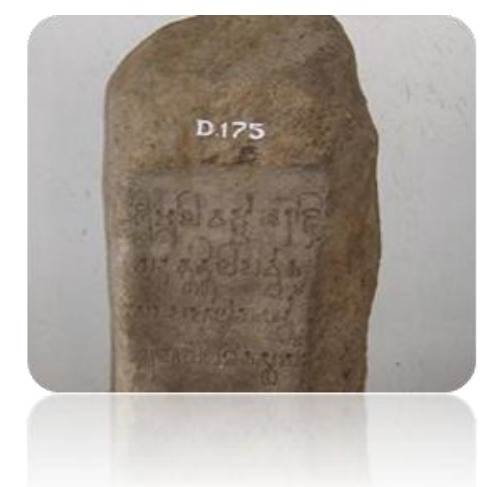

Gambar Prasasti Mulawarman

Isi dari prasasti yang ditemukan tersebut menceritakan puisi dalam bahasa Sansaskerta akan kebaikan Raja Mulawarman dimana isi dari prasasti tersebut diantaranya :

1. Sikap Dhermawan

2. Mulia

3. Saling Mengasihi

4. Mengadakan Kenduri

5. dan Memberi Sedekah (ditempat yang suci).

Kerajaan Kutai dikenal dengan nuansa Agama Hindu yang dipercayai sebagai Kebaikan oleh rakyatnya. Sehingga raja memerintahkan kepada rakyat agar senantiasa menjalankan kebaikan ajaran agama oleh para brahmana sehingga timbul rasa saling mengasihi dan mensejahterakan.

Bukti ditemukan Prasasti tersebut menggambarkan bahwa nilai-nilai Luhur Pancasila telah ada sejak zaman Kerajaan Kutai Kertanegara, Nilai-nilai Pancasila tersebut diantaranya ialah : 1). Nilai Ketuhanan : memeluk agama Hindu. 2). Nilai Kerakyatan : rakyat Kutai hidup sejahtera dan makmur. 3). Nilai Persatuan : wilayah kekuasaannya meliputi hampir seluruh kawasan Kalimantan Timur. 
b. Pancasila pada Zaman Kerajaan Sriwijaya

Pada masa itu tepatnya pada tahun 900 masehi bumi Nusantara (Indonesia) juga memiliki kerajaan yang tersohor hingga keseluruh Asia tenggara, yakni Kerajaan Sriwijaya. Kerajaan Sriwijaya berdiri pada abad ke VII, di bawah kekuasaan Wangsa Sailendra dikenal sebagai Kerajaan Maritim yang mengadakan jalur perhubungan laut. Pada masa itu sistem perdagangan telah diatur dengan baik, supaya rakyat mengalami kemudahan dalam pemasarannya. Selain itu juga sudah ada badan yang bertugas mengurus pajak, harta benda kerajaan, kerohaniawan yang ditugaskan menjadi pengawas teknis pembangunan membuat serta merancang patung-patung suci bagi raja, sehingga kerajaan dapat menjalakan sistem negaranya dengan nilai-nilai ketuhanan.

Cita-cita kesejahteraan bersama dalam suatu Negara telah tercermin dalam Kerajaan Sriwijaya sebagaimana tersebut dalam perkataan "Marvuai Vannua Criwijaya Siddhayatra Subhika" (suatu cita-cita negara yang adil dan makmur). Kerajaan Sriwijaya merupakan kerajaan Melayu yang berada di pulau Sumatera serta memiliki pengaruh besar terhadap Nusantara. Nama kerajaan ini berasal dari Bahasa Sansekerta, sri artinya bercahaya dan wijaya yang memiliki arti kemenangan. Sehingga arti nama kerajaan ini berarti kemenangan yang bercahaya. Daerah kekuasaan Kerajaan Sriwijaya yang meliputi Kamboja, Thailand, Semenanjung Malaya, bahkan hingga Pulau Jawa ini membuat nama Kerajaan Sriwijaya dikenal di seluruh Nusantara. Tidak hanya dari Nusantara saja, akan tetapi juga kerajaan ini dikenal hingga ke mancanegara. Hal ini dibuktikan dengan adanya berbagai sumber yang menyebutkan adanya kerajaan terbesar di Sumatera ini. Ada kabar yang mengatakan bahwa para pedagang dari Arab dan China pernah berdagang di Sriwijaya. Sedangkan menurut 
berita dari India, kerajaan di India pernah bekerja sama dengan kerajaan Sriwijaya.

Sebagai kerajaan yang pernah jaya di Nusantara, tentunya peninggalan kerajaan Sriwijaya tersebar di seluruh daerah kekuasaan mereka. Salah satu jenis peninggalan kerajaan Sriwijaya yang masih ada hingga saat ini adalah berupa prasasti. Berikut ini merupakan prasasti peninggalan kerajaan Sriwijaya.

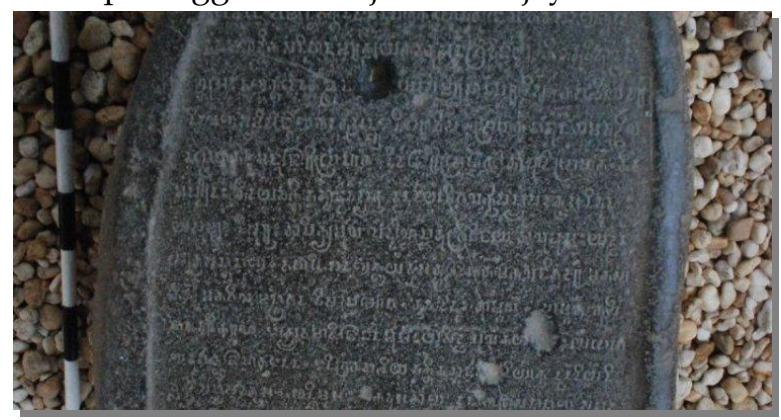

Gambar Prasasti peninggalan Kerajaan Sriwijaya.

1. Prasasti Kota Kapur

Prasasti Kota Kapur merupakan prasasti peninggalan kerajaan Sriwijaya yang berada di bagian barat Pulau Bangka. Bahasa yang ditulis pada prasasti ini menggunakan bahasa Melayu Kuno serta menggunakan aksara Pallawa. Prasasti ini ditemukan sekitar tahun 1892 bulan Desember. Orang yang berhasil menemukan prasasti ini adalah J.K. van der Meulen. Prasasti ini berisi tentang kutukan bagi siapa saja yang membantah perintah serta kekuasaan kerajaan akan terkena kutukan.

2. Prasasti Kedukan Bukit

Seseorang bernama Batenburg menemukan sebuah batu tulis yang berada di Kampung Kedukan Bukit, Kelurahan 35 Ilir pada 29 November 1920 Masehi. Ukuran dari prasasti ini adalah sekitar $45 \times 80$ centimeter serta ditulis menggunakan aksara Pallawa dan bahasa Melayu Kuno.Prasasti ini berisi tentang seorang utusan kerajaan yang bernama Dapunta Hyang yang melakukan perjalanan 
suci atau sidhayarta dengan menggunakan perahu. Dengan diiringi 2000 pasukan, perjalanannya membuahkan hasil. Saat ini, prasasti Kedukan Bukit disimpan di Museum Nasional Indonesia.

\section{Prasasti Telaga Batu}

Prasasti ini ditemukan di sekitar kolam Telaga Biru, Kelurahan 3 Ilir, Kecamatan Ilir Timur II, Palembang. Isi dari prasasti ini adalah mengenai kutukan bagi mereka yang berbuat jahat di Sriwijaya.

4. Prasasti Talang Tuwo

Residen Palembang, yaitu Louis Constant Westenenk menemukan prasasti pada 17 November 1920. Prasasti ini ditemukan di kaki Bukit Seguntang di sekitar tepian utara Sungai Musi. Isi dari prasasti ini berisi doa-doa dedikasi dan menunjukkan berkembangnya agama Buddha di Sriwijaya. Aliran yang digunakan di Sriwijaya adalah aliran Mahayana yang dibuktikan dengan kata-kata dari Buddha Mahayana seperti bodhicitta, vajrasarira, dan lain-lain.

\section{Prasasti Ligor}

Prasasti yang ditemukan di Thailand Selatan ini memiliki dua sisi, yaitu sisi A dan sisi B. Pada sisi A menjelaskan tentang gagahnya raja Sriwijaya. Dalam prasasti tersebut ditulis bahwa raja Sriwijaya merupakan raja dari segala raja dunia yang sudah mendirikan Trisamaya Caiya bagi Kajara. Sedangkan untuk sisi B atau yang disebut prasasti ligor B berisi mengenai pemberian gelar Visnu Sesawarimadawimathana. Gelar tersebut diberikan kepada Sri Maharaja yang mana berasal dari keluarga Sailendravamasa.

6. Prasasti Palas Pasemah

Prasasti Palas Pasemah merupakan prasasti yang berhasil ditemukan di desa Palas Pasemah, Lampung Selatan. Bahasa yang digunakan pada prasasti ini menggunakan bahasa Melayu Kuno dengan aksara Pallawa serta tersusun atas 13 baris kalimat. 
Isi dari prasasti ini berisi tentang kutukan terhadap orang yang tidak tunduk pada kekuasaan Sriwijaya. Diperkirakan, prasasti ini berasal dari abad ke-7 Masehi. Konon, prasasti ini ditemukan di sebuah pinggiran rawa desa.

7. Prasasti Karang Birahi

Kontrolir L.M. Berkhout menemukan prasasti Karang Birahi pada tahun 1904 di sekitar tepian Batang Merangin, Jambi. Isi dari prasasti Karang Birahi juga kurang lebih hampir sama dengan prasasti di poin sebelumnya, yaitu mengenai kutukan bagi mereka yang tidak tunduk terhadap Sriwijaya.

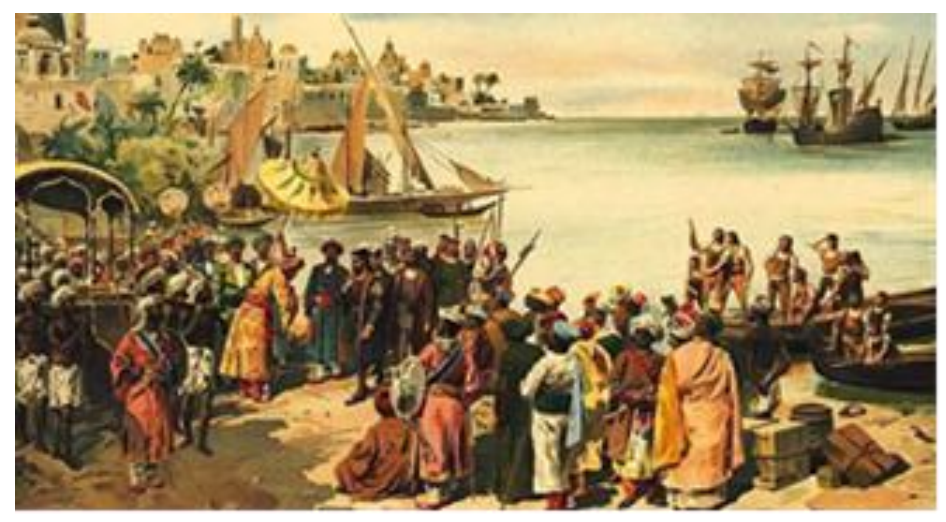

Gambar masa Kerajaan Sriwijaya

Pada hakikatnya nilai-niai budaya Kerajaan Sriwijaya telah menunjukan nilai-nilai Pancasila, yaitu sebagai berikut:

1. Nilai sila pertama, terwujud dengan adanya agama Buddha dan Hindu yang hidup berdampingan secara damai. Pada Kerajaan Sriwijaya terdapat pusat kegiatan pembinaan dan pengembangan agama Buddha.

2. Nilai sila kedua, terjalinnya hubungan antara Sriwijaya dengan India (Dinasti Marsha). Pengiriman para pemuda untuk belajar ke India menunjukan telah tumbuh nilainilai politik luar negeri yang bebas aktif. 
3. Nilai sila ketiga, sebagai Negara Maritim, Kerajaan Sriwijaya telah menerapkan konsep Negara kepulauan sesuai dengan konsep wawasan nusantara.

4. Nilai sila keempat, Kerajaan Sriwijaya telah memiliki kedaulatan yang luas meliputi Siam dan Semenanjung Melayu.

5. Nilai sila kelima, Kerajaan Sriwijaya menjadi pusat pelayanan dan perdagangan sehingga kehidupan rakyatnya sangat makmur.

c. Pancasila pada Zaman Kerajaan Majapahit

Kerajaan Majapahit adalah sebuah kerajaan yang berpusat di Jawa Timur, Indonesia, yang pernah berdiri dari sekitar tahun 1293 hingga 1500 M. Kerajaan ini mencapai puncak kejayaannya menjadi kemaharajaan raya yang menguasai wilayah yang luas di Nusantara pada masa kekuasaan Hayam Wuruk, yang berkuasa dari tahun 1350 hingga 1389. Kerajaan Majapahit adalah kerajaan Hindu-Buddha terakhir yang menguasai Nusantara dan dianggap sebagai salah satu dari negara terbesar dalam sejarah kerajaan di Indonesia. Menurut Negarakertagama, kekuasaannya terbentang di Jawa, Sumatera, Semenanjung Malaya, Kalimantan, hingga Indonesia bagian timur; Kalimantan, Sulawesi, Maluku, Sumbawa, Lombok dan Timor.

Orang hebat yang telah mendirikan kerajaan ini bernama Raden Wijaya. Ia dikukuhkan menjadi seorang Raja dan mendapatkan sebuah gelar Sri Kertajasa Jayawardhana. Raden Wijaya memerintah Majapahit selama 16 tahun hingga akhirnya digantikan oleh Kalagamet atau lebih sering dikenal dengan Sri Jayanegara. Sejak diperintah oleh Raden Wijaya, Majapahit menjadi sebuah kerajaan yang sangat besar. Bahkan termasuk terbesar di Asia bersama dengan kekaisaran China. Saat berdiri, kerajaan ini memiliki negara berupa Surya atau matahari, dan bendera 